\title{
INFLUENCE OF JOB SATISFACTION AND ORGANIZATIONAL COMMITMENT ON LEADER MEMBER EXCHANGE AND EMPOWERMENT OF BEHAVIOR IN ORGANIZATION
}

\author{
Putri Luh Gede Dhavantari Sasmita*, Gorda A.A.N. Eddy Supriyadinata \\ Undiknas Graduate School, Bali, Indonesia \\ ${ }^{\star}$ E-mail: dhavantari.sasmita@gmail.com
}

\begin{abstract}
The purpose of this study was to find out job satisfaction and organizational commitment mediating the influence of leader member exchange and empowerment of the organization citizenship behavior on employees of PT Bank BRI Gajah Mada Branch Denpasar. Samples taken were 161 employees. The analysis technique used is SEM partial least square (PLS) analysis. The results of the analysis show that the member exchange leader has a positive and significant influence on the organization citizenship behavior. Empowerment has a positive and significant influence on the organization citizenship behavior. Leader member exchange has a positive and significant influence on employee job satisfaction. Empowerment has a positive and significant influence on the organization citizenship behavior. The member exchange leader has a positive and significant influence on organizational commitment. Empowerment has a positive and significant influence on organizational commitment. Job satisfaction has a positive and significant influence on organizational citizenship behavior. Organizational commitment has a positive and significant influence on organizational citizenship behavior. Job Satisfaction has a significant positive effect as a variable that is able to mediate leader member exchange, empowerment towards organizational citizenship behavior. Organizational commitment has a significant positive effect as a variable that is able to mediate leader member exchange, empowerment towards organizational citizenship behavior behavior in employees of PT Bank BRI Gajah Mada Branch Denpasar.
\end{abstract}

\section{KEY WORDS}

Leader member exchange, empowerment, organizational commitment, job satisfaction, organizational citizenship behavior.

Companies that succeed in realizing change have the characteristics of being able to move faster, aware of the importance of organizational citizenship behavior in improving product quality, increasing involvement of organizational members, customer orientation, and organizations whose structure leads to a more flat form and not a pyramid (Arif and Ratna, 2015). In the face of intense competition in the business world today, companies need a quality workforce to produce good company performance in order to win the competition (Arina et al., 2016). The role of human resources (HR) is one of the most important elements that will realize and turn the wheels of the company to continue going forward (Arif and Ratna, 2015).

A factor that has an important role to OCB is the leader member exchange (LMX). Robbins (2015: 359) leadership leader member exchange (LMX) can be defined as: "Creation by leaders in groups and groups, where subordinates are distinguished from group statuses that have higher performance ranks with greater job satisfaction". In connection with this definition, it can be seen that in LMX found differences in attitudes received by subordinates from their superiors.

Another factor influencing the implementation of OCB is the empowerment. Empowerment is the authority to make decisions in a certain area of operational activities without having to obtain authorization from others (Luthans, 2014: 78). Empowerment is giving authority to employees to plan (control), control (Controlling) and make decisions on 
the work for which they are responsible without having to get explicit authorization from their superiors.

Basically, someone at work will feel comfortable and show a high level of loyalty to the organization, if at work feel satisfaction in accordance with what they want. Handoko (2014: 112) states that job satisfaction is a pleasant or unpleasant emotional state in which employees view their work. Gorda (2006: 89) explains that job satisfaction is a major determinant of employee OCB. Job satisfaction is a positive feeling about someone's job which is the result of an evaluation of its characteristics (Rivai, 2014: 79).

Dhanalaksmi \& Blanga (2014) states that organizational commitment is one of the keys in maintaining employee performance. Organizations will run well when supported by talent management and organizational commitment (Dhanalaksmi \& Blanga, 2014). Solomon \& Sandhya (2014) states organizational commitment is defined by some researchers as a measure of the strength of identity and employee involvement in organizational goals and values.

Based on The Porter-Lawler Model Theory (Steer, 1996: in Mukundu, 2014) states that the perception contained in employees will be an attitude of job satisfaction. The satisfaction assessment that he has felt will be re-assessed as value, and coupled with the implementation of the company's empowerment, the attitude of the leadership that is carried out to nurture employees in the future is likely to be valued by the company more. The effort that will be carried out will produce an attitude of high commitment, so that employees have an extra-role attitude to do the work, adjusting to their abilities and understanding of organizational citizenship behavior.

As one of the government banks that have a large number of human resources, Bank $\mathrm{BRI}$ should be able to be more competitive to become the best bank in Indonesia. To create competitiveness, of course, human resources owned must be stimulated and motivated to provide the best performance for the company. In a study found that employee satisfaction in terms of employee involvement, job satisfaction has a relationship and influence in improving the results of business units including company profits (Dyah et al., 2014).

Seeing these problems, the authors are interested in conducting research with the title "Leader Member Exchange and Empowerment in Organizational Citizenship Behavior: Satisfaction and Commitment as Intervening.

\section{LITERATURE REVIEW}

In 1977 for the first time the term organizational citizenship behavior (OCB) was introduced by Organs, and defined organizational citizenship behavior (OCB) as individual behavior that is free (discretionary), which does not directly and explicitly receive an award from the formal reward system, and which as a whole encourages the effectiveness of organizational functions (Murphy, 2014). Free in the sense that the behavior is not a requirement that must be carried out in a particular role or job description, or behavior that is a personal choice (Podsakoff et al, 2014: 513). 2016):

Indicators that influence organizational citizenship behavior are as follows (Arina et al.,

1. Altruism, namely behavior that prioritizes the interests of others, for example helping colleagues;

2. Concientiousness, behavior that is part of employees who carry out tasks that exceed the minimum prerequisites;

3. Sporsmanship or sportsmanship, the feeling of employees to refrain from complaints about things that are not liked, including working without complaining;

4. Courtesy, behavior that is part of an individual to replace others in the organization about changes that affect their work;

5. Civic virtue, behavior that is part of individuals who identify that they participate in the company, for example always looking for new information.

The understanding of leader member exchange (LMX) as Robbins (2015: 198) argues that "leader member exchange is an improvement in the quality of the relationship between 
supervision and employees will be able to improve the work of both. But in reality, the relationship between employees and supervision can be grouped into two relationships, namely good relationships and bad relationships. A good relationship will create employee trust, positive attitude, and loyalty, but a bad relationship has the opposite effect.Leader

Indicator variable leader member exchange according to Mahmut et al. (2015) there are three indicators of leader member exchange, namely:

1. Respect, the relationship between superiors and subordinates cannot be formed without mutual respect for the abilities of others;

2. Trust, without mutual trust, the relationship between superiors and subordinates will be difficult to form;

3. Bonds, the effect of obligations will develop into a working relationship between superiors and subordinates.

Luthans (2014: 114) defines empowerment as giving responsibility and authority to work to make decisions regarding all product development and decision making. Empowerment is an ongoing interpersonal relationship to build trust between employees and management. Frans (2015) gives the meaning of empowerment as a form of decentralization which involves subordinates in making decisions. as follows.

Through the understanding expressed by Luthans (2014) the indicators assessed are

1. Providing opportunities to identify problems;

2. Provide opportunities to participate;

3. Provide adequate time and resources;

4. Provide training;

5. Provide time to get information.

Basically job satisfaction is an individual thing. Each individual will have a different level of satisfaction in accordance with the system of values that apply to him. This is due to differences in each individual. The more aspects of the work in accordance with the wishes of the individual, the higher the level of satisfaction he feels, and vice versa (Robbins, 2015: 103).

According to Luthans (2014: 112), there are four dimensions to measure satisfaction variables, including:

1. Satisfaction of working conditions is a comfortable and pleasant working condition so that physical needs are met and lead to job satisfaction;

2. Satisfaction with leadership is the ability of management to provide technical assistance and behavioral support through a communication process for a particular purpose;

3. Responsibility is a series of tasks and activities carried out to achieve work results and employee responsibilities;

4. Extrinsic rewards are salaries, wages, rewards paid based on performance and pay protection programs outside of working hours, facilities for employees.

Luthans (2014: 82) defines organizational commitment as an attitude that reflects employee loyalty to the organization and is an ongoing process in which members of the organization express their attention to the organization, towards organizational success and sustainable progress (Ayu, 2016). Organizational commitment is an affective response to the organization. Some experts define organizational commitment in different forms but have the same meaning. Robbins (2015: 97) organizational commitment is defined as a condition in which an individual sides with the organization and its goals and desires to maintain its membership in the organization. as follows.

Through the understanding expressed by Luthans (2014) the indicators assessed are

1. Affective commitment (emotional commitment): employee emotional attachment, and involvement in organizational;

2. Continued commitment: commitment based on losses associated with leaving employees from the organization. This may be due to loss of seniority for promotion or benefits; 
3. Normative Commitment: the feeling of being obliged to remain in the organization because it must be so; the action is the right thing to do.

\section{CONCEPTUAL FRAMEWORK}

Based on a review of the theory and the results of previous studies, the research model can be described as follows:

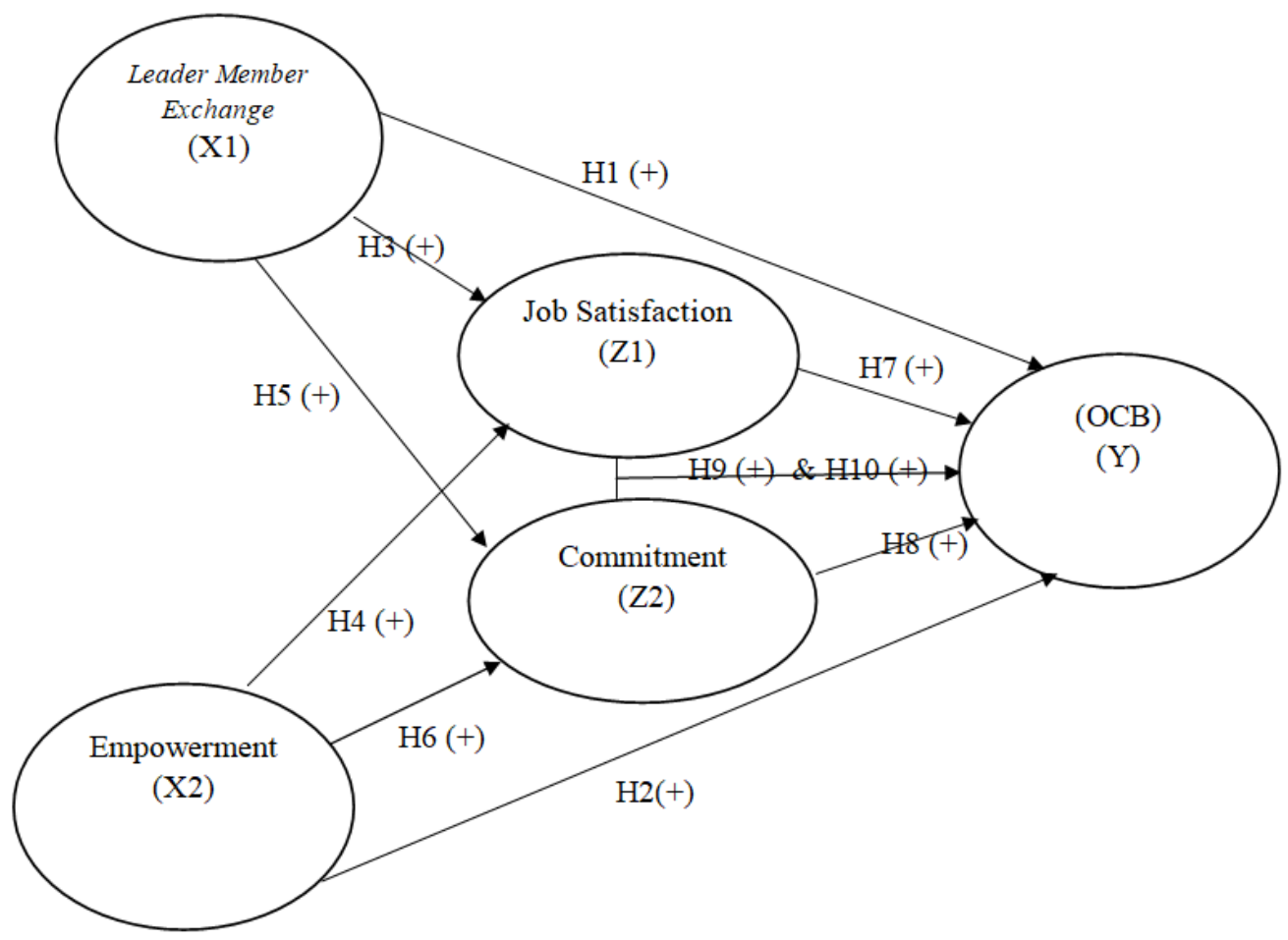

Figure 1 - Conceptual Framework

Research Hypothesis:

- H1: The better Leader Member Exchange is, the more Organizational Citizenship Behavior will increase;

- $\mathrm{H} 2$ : The better the Empowerment, the more Organizational Citizenship Behavior will increase;

- H3: The better the Leader Member Exchange, the more Job Satisfaction increases;

- H4: The better the Empowerment, the more Job Satisfaction increases;

- H5: The better Leader Member Exchange, the more Organizational Commitment increases;

- H6: The better the Empowerment, the more Organizational Commitment increases;

- H7: The better Job Satisfaction, the more Organizational Citizenship Behavior will increase;

- H8: The better the Organizational Commitment, the more Organizational Citizenship Behavior will increase;

- H9: The better Job Satisfaction will mediate the Effects of Leader Exchange Members and Empowerment on Organization Citizenship Behavior;

- H10: The better the Organizational Commitment will mediate the Effect of Leader Member Exchange and Empowerment on Organization Citizenship Behavior.

\section{METHODS OF RESEARCH}

The research location is a place or region where the research will be conducted where PT. Bank BRI Gajah Mada Branch located at Jl. Gajah Mada No.5-7, Dauh Puri Kangin, 
West Denpasar, Denpasar City, Bali. PT. BRI Bank is the first government bank in Indonesia, which currently has 30 percent of its shares sold to the public so that now PT. Bank BRI has changed into a limited liability company (www.bri.co.id). Until 2010, PT. Bank BRI is included in the top ten largest banks in Indonesia, and PT. Bank BRI entered the second position.

Population according to Sugiyono (2014: 148) is a generalization area consisting of objects / subjects that have certain qualities and characteristics determined by researchers to be studied and then conclusions drawn. From the above understanding it can be said that the population is an object or subject that is in an area that meets certain requirements related to the research problem. The population in this study is employees who work at BRI Bank Gajah Mada Denpasar Branch. The population in this study was 229 permanent and contract employees.

The research sample is a portion of the population that can represent the population, from 161 employees outside the branch manager, sub-branch manager, marketing manager, operational manager and micro business manager. The large number of employee samples obtained was 161 people. The sample will be used based on the census method (Sugiyono, 2014: 73) because members of the population are homogeneous and truly representative (representative) so that they can represent the entire population.

Analysis of the data used in this study is CB-SEM (Covariance Based-Structural Equation Modeling) with the AMOS (Analysis of Moment Structure) program. AMOS is an abbreviation of Analysis of Moment Structure, developed by Dr. J. Arbuckle, which is one of the new and most sophisticated generation programs today to process multidimensional and tiered research models (Ferdinand, 2014: 83).

\section{RESULTS AND DISCUSSION}

The results of the path coefficient validation test for each path for direct effects and effects can be presented in Table 1 below.

Table 1 - Direct Effect Testing Results

\begin{tabular}{|c|l|c|c|c|}
\hline No. & \multicolumn{1}{|c|}{ Relationship Between Variabel } & $\begin{array}{c}\text { Original sample } \\
\text { estimate }\end{array}$ & T Statistic & Information \\
\hline 1 & $\begin{array}{l}\text { Leader member exchange }\left(\mathrm{X}_{1}\right) \rightarrow \text { organization citizenship } \\
\text { behavior }\left(\mathrm{Y}_{1}\right)\end{array}$ & 0.491 & 4.698 & Significant \\
\hline 2 & Empowerment $\left(\mathrm{X}_{2}\right) \rightarrow$ organization citizenship behavior $\left(\mathrm{Y}_{1}\right)$ & 0.671 & 6.862 & Significant \\
\hline 3 & Leader member exchange $\left(\mathrm{X}_{1}\right) \rightarrow$ Satisfaction $\left(\mathrm{Z}_{1}\right)$ & 0.728 & 7.817 & Significant \\
\hline 4 & Empowerment $\left(\mathrm{X}_{2}\right) \rightarrow$ Satisfaction $\left(\mathrm{Z}_{1}\right)$ & 0.572 & 7.919 & Significant \\
\hline 5 & Leader member exchange $\left(\mathrm{X}_{1}\right) \rightarrow$ Commitment $\left(\mathrm{Z}_{2}\right)$ & 0.465 & 8.287 & Significant \\
\hline 6 & Empowerment $\left(\mathrm{X}_{2}\right) \rightarrow$ Commitment $\left(\mathrm{Z}_{1}\right)$ & 0.431 & 8.527 & Significant \\
\hline 7 & $\begin{array}{l}\text { Job satisfaction }\left(\mathrm{Z}_{1}\right) \rightarrow \text { Organizatinal citizenship behavior } \\
\left(\mathrm{Y}_{1}\right)\end{array}$ & 0.403 & 8.517 & Significant \\
\hline 8 & Commitment $\left(\mathrm{Z}_{2}\right) \rightarrow$ Organizatinal citizenship behavior $\left(\mathrm{Y}_{1}\right)$ & 0.548 & 8.832 & Significant \\
\hline
\end{tabular}

Source: Processed Data Results, 2019.

Information from Table 1, the hypothesis test results can be determined which are described in the following description:

1. Leader member exchange is proven to have a positive and significant effect on organizational citizenship behavior. These results are shown by a positive path coefficient of 0.491 with a t-statistic of 4.698 (t-statistics $>1.96)$, thus, hypothesis $1(\mathrm{H} 1)$ can be proven;

2. Empowerment is proven to have a positive and significant effect on organizational citizenship behavior. These results are shown by a positive path coefficient of 0.671 with a tstatistic of 6.862 (t-statistics> 1.96), thus, hypothesis $2(\mathrm{H} 2)$ can be proven;

3. Leader member exchange is proven to have a positive and significant effect on satisfaction. This result is shown by a positive path coefficient of 0.728 with a t-statistic of 7.817 (t-statistic> 1.96), thus, hypothesis $3(\mathrm{H} 3)$ can be proven; 
4. Empowerment is proven to have a positive and significant effect on satisfaction. This result is shown by a positive path coefficient of 0.572 with a t-statistic of 7.919 (t-statistics> 1.96), thus, the hypothesis $4(\mathrm{H} 4)$ can be proven;

5. Leader member exchange is proven to have a positive and significant effect on organizational commitment. This result is shown by a positive path coefficient of 0.465 with a t-statistic of 8.287 (t-statistic> 1.96), thus, hypothesis 5 (H5) can be proven;

6. Empowerment is proven to have a positive and significant effect on organizational commitment. This result is shown by a positive path coefficient of 0.431 with a t-statistic of 8.527 (t-statistics> 1.96), thus, hypothesis $6(\mathrm{H} 6)$ can be proven;

7. Satisfaction has been proven to have a positive and significant effect on organizational citizenship behavior. These results are shown by a positive path coefficient of 0.403 with a t-statistic of 8.517 (t-statistics $>1.96)$, thus, hypothesis $7(\mathrm{H} 7)$ can be proven;

8. Organizational commitment is proven to have a positive and significant effect on organizational citizenship behavior. This result is shown by a positive path coefficient of 0.548 with a t-statistic of 8.832 (t-statistic $>1.96)$, thus, hypothesis $8(\mathrm{H} 8)$ can be proven.

The results of the mediation test use the method proposed by Hair et al., (2011) which can subsequently be proven to be intervening from the mediating variable criteria as follows:

Table 2 - Mediation Effect Testing Results

\begin{tabular}{|c|l|c|c|c|}
\hline No. & \multicolumn{1}{|c|}{ Relationship Between Variables } & $\begin{array}{l}\text { Path coefficient } \\
\text { (Bootstrapping) }\end{array}$ & TStatistic & Information \\
\hline 1 & $\begin{array}{l}\text { Job Satisfaction }\left(\mathrm{Z}_{1}\right) \rightarrow \text { Leader member exchange }\left(\mathrm{X}_{1}\right) \rightarrow \\
\text { Empowerment }\left(\mathrm{X}_{2}\right) \rightarrow \text { organization citizenship behavior }\left(\mathrm{Y}_{1}\right)\end{array}$ & 0.587 & 8.721 & Significant \\
\hline 2 & $\begin{array}{l}\text { Commitment }\left(\mathrm{Z}_{2}\right) \rightarrow \text { Leader member exchange }\left(\mathrm{X}_{1}\right) \rightarrow \\
\text { Empowerment }\left(\mathrm{X}_{2}\right) \rightarrow \text { organization citizenship behavior }\left(\mathrm{Y}_{1}\right)\end{array}$ & 0.541 & 8.662 & Significant \\
\hline
\end{tabular}

Source: Processed Data Results, 2019

Information from Table 1, the hypothesis test results can be determined which are described in the following description:

1. Satisfaction is proven to mediate the influence of leader member exchange and empowerment on organization citizenship behavior. This result is shown by a positive path coefficient of 0.587 with a t-statistic of 8.721 (t-statistic > 1.96), thus, hypothesis 9 (H9) can be proven;

2. Organizational commitment is proven to mediate the influence of leader member exchange and empowerment to organization citizenship behavior. This result is shown by a positive path coefficient of 0.541 with a t-statistic of 8.662 (t-statistic> 1.96), thus, the hypothesis $10(\mathrm{H} 10)$ can be proven.

\section{CONCLUSION}

Leader member exchange has a positive and significant influence on organization citizenship behavior. This shows that the better the application of leader member exchange, the higher the organizational citizenship behavior of employees at PT Bank BRI Gajah Mada Denpasar Branch.

Empowerment has a positive and significant influence on organizational citizenship behavior. This shows that the better the implementation of empowerment, the higher organizational citizenship behavior of employees at PT Bank BRI Gajah Mada Branch Denpasar.

Leader member exchange has a positive and significant effect on employee job satisfaction. This shows that the better the implementation of leader member exchange, the higher the job satisfaction of employees at PT Bank BRI Gajah Mada Denpasar Branch.

Empowerment has a positive and significant influence on organizational citizenship behavior. This shows that the better the empowerment carried out by management, the higher the job satisfaction of employees at PT Bank BRI Gajah Mada Branch Denpasar. 
Leader exchange members have a positive and significant influence on organizational commitment. This shows that the better the implementation of leader member exchange, the higher the organizational commitment of employees at PT Bank BRI Gajah Mada Branch Denpasar.

Empowerment has a positive and significant influence on organizational commitment. This shows that the better the empowerment carried out by management, the higher the organizational commitment of employees at PT Bank BRI Gajah Mada Branch Denpasar.

Job satisfaction is a positive and significant effect on organizational citizenship behavior. This shows that the higher employee job satisfaction, the higher the organizational citizenship behavior of employees at PT Bank BRI Gajah Mada Denpasar Branch.

Organizational commitment has a positive and significant effect on organizational citizenship behavior. This shows that the higher the organizational commitment of employees, the higher organizational employee citizenship behavior at PT Bank BRI Gajah Mada Denpasar Branch.

Job Satisfaction has a significant positive effect as a variable capable of mediating leader member exchange, empowerment of organizational citizenship behavior. This shows that job satisfaction is able to be a full mediating variable in the relationship of leader member exchange and empowerment of organizational citizenship behavior of employees at PT Bank BRI Gajah Mada Branch Denpasar.

Organizational commitment has a significant positive effect as a variable capable of mediating leader member exchange, empowering organizational citizenship behavior. This shows that organizational commitment is able to become a variable of full mediation in the relationship of leader member exchange and empowerment of organizational citizenship behavior of employees at PT Bank BRI Gajah Mada Branch Denpasar.

\section{REFERENCES}

1. Abdillah, W., and Jogiyanto. (2015). Partial Least Square (PLS) Alternatif Structural Equation Modeling (SEM) dalam Penelitian Bisnis (edisi 1). Yogyakarta: Andi.

2. Ali Chitsaz-Isfahani, Hamid Reza Boustani. (2014). Effect of Talent Management on Employees Retention: The Mediate Effect of Organizational Trust, International Journal of Academic Research in Economics and Management Sciences, 3 (5): 1-15.

3. Arikunto (2016). Prosedur Penelitian Suatu Pendekatan Praktik. Jakarta: Rineka Cipta.

4. Alexious, Mukundu. (2014). The Incremental Validity Of Cash Incentive Satisfaction Over Affective Commitment, Procedural, Justice, And Leadership Trust In Predicting Organisational Citizenship Behaviors, University of Zimbabwe.

5. Bakan, Ismail, Tuba Buyukbese, Burcu Frsahan and Ilker Kefe. (2014). The Effect of Organizational Commitment on Women Employee Organizational Citizenship Behavior, Indian Journal of Applied Research, 3 (2): 202-204.

6. Dennis W. Organ, Mackenzie, Podsakoff. (2016). Organizational Citizenship Behavior: It's Nature, Antecendents and Concequences. Sage Publications, Inc: California.

7. Dhanalaksmi, Blanga Gurunathan. (2014). A Study On Talent Management A Strategy To Influence Employee Engagement And Its Affect On The Organizational Outcome, International Journal of Business and Administration Research Review, 2 (4): 1-11.

8. Fomolo, F. (2014). The Impact of Leader-Member Exchange, Employee Empowerment and Affective Commitment on TRNC Hotel and Restaurant Workers: Implications for Retention, International Journal Hospitality and Tourism, 2 (3): 1-30.

9. Ferdinand, A. (2014). Stuructural Equation Modeling. Semarang: Badan Penerbit Universitas Diponegoro.

10. Ghozali, I. Latan, H. (2015). Partial Least Square: Konsep, Teknik and Aplikasi SmartPLS 2.0 M3. Semarang: Badan Penerbit Universitas Diponegoro.

11. Gorda (2006). Manajemen Sumber Daya Manusia, Edisi Revisi. Denpasar: Bali.

12. Hidayat, Arif, Ratna Kusumawati. (2015). Pengaruh Komitmen Organisasi and Kepuasan Kerja terhadap Organization Citizenchip Behavior (OCB) di PT. Argamukti Pratama Semarang, Jurnal Manajemen Bisnis, 2 (4): 1-15. 
13. Kusumowardani (2016). Analisis Pengaruh Manajemen Talenta and Global Midnset Terhadap Turnover Intention dengan Komitmen Organisasi Sebagai Variabel Intervening (PT. Cipta Busana Mandiri Demak), Jurnal Diponegoro of Management. 5 (3): 1-15.

14. Hair, et al. (2014). Multivariate Data Analysis. New Jersey: Pearson Education.

15. Handoko T. Hani. (2014). Manajemen Personalia and Sumber Daya Manusia Edisi 2, Yogyakarta: BPFE UGM.

16. Husein, Umar. (2014). Metode Penelitian Untuk Skripsi and Tesis Bisnis. Jakarta: PT Rajagrafindo Persada.

17. Kenneth J. Harris, 2016. Leader-member Exchange and Empowerment: Direct and Interactive Effects on Job Satisfaction, Turnover Intentions, and Performance, Journal of The Leadership Quarterly, 20 (1): 371-382.

18. Luthans, Fred. (2014). Perilaku Organisasi, Edisi kesepuluh. Andi Offset.

19. Murphy, Gregory, Athanasou, James. (2014). Job Satisfaction and Organizational Citizenship Behavior, a Study of Australian Human Service Professionalis, Journal of Managerial Psychology, 17 (4): 287-297.

20. Ozdevecioglu, Mahmut (2015). Effect of Leader-Member Exchange (LMX) on Turnover Intentions and Organizational Citizenship Behavior the Mediating Role of Meaningful Work, International Journal of Management and Innovation, 5 (6): 710-719.

21. Paramita, Arina Ratna., Mudji Rahardjo., Syuhada Sofian. (2016). Analisis Faktor-faktor yang Mempengaruhi OCB Pegawai Kontrak (Studi Pada Pegawai Kontrak di Lingkungan Universitas Diponegoro Semarang), Jurnal Studi Manajemen Organisasi, 4 (2): 61-69.

22. Permata, P.R. (2016). Analisis Pengaruh Sistem Reward, Motivasi Kerja, and Komitmen Organisasional Terhadap Retensi Karyawan (Studi Pada Karyawan PT Primayudha Mandirijaya), Jurnal Diponegoro Management, 1 (3): 1-56.

23. Podsakoff, P.M, Mackenzie, S.B. (2014). Organizational Citizenship Behavior. A Critical Review of Theoretical Emprical Literatrure and Suggestions for Future Research, Journal of Managemant, 26 (3): 513-563.

24. Rajkumar, P., Bhuvaneswari, G. (2016). Employee Empowerment and Employee Turnover Intention-an Empirical Analysis in Life Insurance Sector, International Journal Business Review, 13 (8): 6355-6367.

25. Rini, Dyah Puspita (2014). Pengaruh Komitmen Organisasi, Kepuasan Kerja and Budaya Organisasi terhadap Organization Citizenchip Behavior (OCB) (Studi pada PT. Plasa Simpanglima Semarang), Jurnal IImiah Dinamika, 1 (1): 69-88.

26. Rivai (2014). Kepemimpinan and Perilaku Organisasi. PT. Raja Grapindo Persada.

27. Robbins, Stephen P. (2015). Perilaku Organisasi. Edisi kesepuluh. Jakarta: PT Indeks Kelompok, Gramedia.

28. Robbins, S.P. (2015). Perilaku Organisasi, Edisi Kedua belas. Jakarta: Salemba Empat.

29. Santoso, Singgih. (2014). Statistik Non Parametrik Konsep and Aplikasi dengan SPSS, Jakarta: PT. Elex Media Komputindo.

30. Solomon Markos (2014). Employee Engagement: The Key to Improving Performance, International Journal of Business and Management, 5 (12): 89-96.

31. Sudirjo, Frans. (2015). Pengaruh Leader Member Exchange and Pemberdayaan melalui Mediasi Komitmen Organisasional Terhadap Turnover Intention (Studi Pada Kantor Notaris di Provinsi Jawa Tengah), Jurnal Ekonomi and Kewirausahaan. 3 (1): 1-1.

32. Sepdiningtyas, R. (2017). The Influence of Leader-Member Exchange on Individual Performance: The Roles of Work Engagement as a Mediating Variable and Co-Workers Support as a Moderating Variabl, Review of Integrative Business and Economics Research, 6 (4): 285-305.

33. Sugiyono. (2014). Metode Penelitian Bisnis. Bandung: CV Alfabeta.

34. Wickramasinghe, Vathsala, and Chandrasekara, Rasika. (2014). Differential effects of employment status on work-related outcomes A pilot study of permanent and casual workersin Sri Lanka, Journal of Employee Relation, 33 (5): 532-550.

35. Yafang, Tsai, Wu S.W. (2015). The Relationship among Job Satisfaction, Organizational Citizenship Behavior and Turnover Intention. Northeast Decision Sciences Institute Proceedings. 